\title{
Cytokine Networks Dysregulation during HTLV-1 Infection and Associated Diseases
}

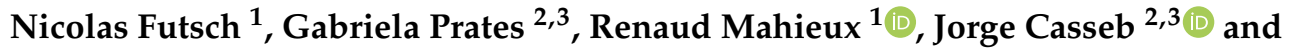 \\ Hélène Dutartre ${ }^{1, *(\mathbb{D})}$ \\ 1 Équipe Oncogenèse Rétrovirale, Equipe Labellisée «FRM», CIRI-Centre International de Recherche en \\ Infectiologie, Université Claude Bernard Lyon 1, Inserm U1111, CNRS UMR5308, Labex Ecofect, ENS Lyon, \\ F-69007 Lyon, France; nicolas.futsch@ens-lyon.fr (N.F.); renaud.mahieux@ens-lyon.fr (R.M.) \\ 2 Institute of Tropical Medicine of São Paulo, São Paulo, SP 05403-000, Brazil; \\ gabrielaprates12@hotmail.com (G.P.); jcasseb10@gmail.com (J.C.) \\ 3 Laboratory of Dermatology and Immunodeficiencies, Department of Dermatology, \\ University of São Paulo Medical School, São Paulo, SP 01246-100, Brazil \\ * Correspondence: helene.dutartre@ens-lyon.fr
}

Received: 27 September 2018; Accepted: 30 November 2018; Published: 5 December 2018

\begin{abstract}
Human T-cell leukemia virus type 1 (HTLV-1) is the causative agent of a neural chronic inflammation, called HTLV-1-associated myelopathy/tropical spastic paraparesis (HAM/TSP) and of a malignant lymphoproliferation, called the adult T-cell leukemia/lymphoma (ATLL). The mechanisms through which the HTLV-1 induces these diseases are still unclear, but they might rely on immune alterations. HAM/TSP is associated with an impaired production of pro-inflammatory cytokines and chemokines, such as IFN- $\gamma$, TNF- $\alpha$, CXCL9, or CXCL10. ATLL is associated with high levels of IL-10 and TGF- $\beta$. These immunosuppressive cytokines could promote a protumoral micro-environment. Moreover, HTLV-1 infection impairs the IFN-I production and signaling, and favors the IL-2, IL-4, and IL-6 expression. This contributes both to immune escape and to infected cells proliferation. Here, we review the landscape of cytokine dysregulations induced by HTLV-1 infection and the role of these cytokines in the HTLV-1-associated diseases progression.
\end{abstract}

Keywords: HTLV-1; immune system; HAM/TSP; ATLL; cytokines

\section{Introduction}

Human T-cell leukemia virus type 1 (HTLV-1), the first oncogenic retrovirus identified in humans, is the etiological agent of two main diseases-HTLV-1-associated myelopathy/tropical spastic paraparesis (HAM/TSP) and the adult T-cell leukemia/lymphoma (ATLL). Both diseases generally occur after a long period of latency, with approximatively, 1 to $2 \%$ and 2 to $4 \%$ of carriers being at risk for HAM/TSP or ATLL development, respectively [1]. An increased HTLV-1 proviral load is observed both in ATLL and HAM/TSP patients [2]. In addition, both diseases seem not only to be driven by HTLV-1 itself but also through potential interactions between the virus and its host, although mechanisms leading to HAM/TSP or ATLL development, are not fully understood. HTLV-1 provirus is found in several cell types in vivo. This includes CD4+T and CD8+ T cells, neutrophils, monocytes, myeloid and plasmacytoids dendritic cells [3,4]. In vitro HTLV-1 infection has been reported in CD4+ and CD8+ T cells [5], myeloid and plasmacytoid dendritic cells [6], and monocytes-derived dendritic cells [3,7]. Although mainly analyzed in infected T-cells, HTLV-1 infection may perturb the ability of all these different cell types to secrete cytokines.

HTLV-1 is endemic in Japan, sub-Saharan Africa, the Caribbean region and South America (especially in Brazil), in addition to a small foci in the Middle East, Romania, and Australo-Melanesia [8]. 
Inter-individual transmission of HTLV-1 is the result of a direct exposure to infected cells which are present either in maternal milk, semen, or blood [1]. There seems to be a higher risk of developing HAM/TSP in the Caribbean and South America, while ATLL is the main HTLV-1-associated disease in Japan [8]. It has been suggested that the risk of ATLL development was mainly associated with a mother-to-child transmission of the virus [9], while the risk of HAM/TSP development results from infections through contaminated blood or sexual contacts $[10,11]$. However, the transmission route may not be the exclusive driver of disease onset, since ATLL cases were reported among patients with HAM/TSP [12]. In addition, HAM/TSP or ATLL diseases also occurred in young patients who had likely acquired the virus through breastfeeding [13].

HAM/TSP was defined as a progressive, chronic demyelination of the spinal cord, associated with an accumulation of both HTLV-1-infected cells and CD8+ T-cells, directed against HTLV-1 antigens, within the cerebrospinal fluid (CSF) and neural tissues [14-17]. ATLL is described as a highly aggressive HTLV-1-infected CD4+ T-cells proliferation and was classified into four clinical subtypes, i.e., smoldering, chronic, acute, and lymphoma subtypes [18].

Both diseases are characterized by an alteration in the immune system. While HAM/TSP is associated with a chronic inflammation, instrumental for the symptom's manifestation, ATLL is characterized by an immunosuppressive state that favors the proliferation of the transformed HTLV-1-infected cells, thus, contributing to the malignancy. These different immune profiles are sustained by different cytokine networks, which may contribute to the specific HTLV-1-induced diseases development. However, the reasons for the disease occurrence in each HTLV-1 infected individual are still an important unanswered question. Markers of the disease evolution towards ATLL or HAM/TSP have not been identified. In this review, we try to explain how the interaction of the HTLV-1 with the immune system leads to a potential dysregulation of cytokines production or signaling, thus, allowing viral persistence and, eventually, pathogenesis.

\section{Cytokines Supporting HTLV-1-Infected T-Cells Proliferation and Survival}

A hallmark of the HTLV-1-infected T-cells is their ability to proliferate independent of the TCR (T-cell Receptor) signaling, due to immortalization of the infected-cells This mainly requires activity of the Tax and the HBZ (HTLV-1 Basic Leucine Zipper Factor) viral proteins [19,20]. Survival and proliferation of the HTLV-1-infected cells are also supported by their dependence on several cytokines, such as IL-2, IL-4, IL-6, and IL-13 (Figure 1).

\subsection{IL-2}

IL-2 signaling induces cell proliferation and inhibition of apoptosis in human T-cells [21]. HTLV-1-infected cells isolated from asymptomatic carriers, HAM/TSP patients, and ATLL patients are all able to express the IL-2 receptor (IL-2R, CD25), mainly, because of the well-documented transcriptional effect of Tax on CD25 promotor [22]. However, only fresh HTLV-1-infected T-cells isolated from asymptomatic carriers and HAM/TSP patients express IL-2 mRNA [23], supporting an autocrine IL-2 proliferation loop in these individuals [24]. In line with this, it was reported that in vitro infected Peripheral Blood Mononuclear Cells (PBMCs) were dependent on IL-2, for their proliferation, until they get immortalized after several weeks in culture [25]. In these HTLV-1 infected T-cell lines, some characteristic of partial IL-2 independence, with constitutive JAK3/STAT3 phosphorylation, in the absence of IL2, was linked to the immortalization process. Consistently, leukemic cells from the ATLL patients, that are fully immortalized and transformed, are poorly or fully non-responsive to IL-2, for their proliferation [26-28], which could be associated with the low levels of IL-2 secreted by the HTLV-1-infected cell lines [29]. These studies suggest that the proliferation of leukemic cells in vivo could be partly IL-2 independent. Indeed, it has been reported that some HTLV-1-infected T-cells can proliferate without any addition of the exogenous IL-2 [29]. This IL-2-independent proliferation could result from a constitutive activation of the JAK/STAT (Janus kinases/Signal Transducer and Activator of Transcription) signaling [30], as exemplified by the constitutive phosphorylation of the 
STAT5 observed in IL-2-independent HTLV-1-infected T-cell lines [31]. However, this was observed in leukemic cells in only a small proportion of ATLL patients [31,32], suggesting that IL-2 dependent mechanisms could, nevertheless, contribute to the proliferation of the HTLV-1-infected cells in ATLL patients. Furthermore, CD25 expression on ATLL cells, may sequester IL-2, rather than induce IL-2 signaling, as could the soluble form of CD25, although, it was observed in humanized mice, infected by HTLV-1 [33]. In addition, IL-9 or IL-15, combined with IL-2, could better sustain the proliferation of PBMCs from chronic or smoldering ATLL patients, than IL-2 alone [34]. Interestingly, IL-9 expression is induced by both Tax and IL-2 [35], and the IL-15 receptor is expressed at the surface of leukemic cells, from the HTLV-1-infected patients [36]. Finally, the spontaneous proliferation of leukemic cells from chronic or smoldering ATLL patients is inhibited if they are sorted from the total PBMCs population [34]. Even though the proliferation of these isolated leukemic cells is not enhanced by IL-2 or IL-9 addition, it is restored after an interaction with autologous monocytes [34], thus, suggesting that in vivo leukemic cell proliferation may not only rely on cytokine loops but also on physical contacts with surrounding cells. Finally, a recent report showed that ATLL cell proliferation relies on the HBZ-induced BATF3 expression and BATF3/IRF4 network [37]. This further supports the fact that ATLL cells growth is not regulated through the IL-2 autocrine loop.

\section{2. $I L-4$}

IL-4 induces leukemic cells proliferation, when cells isolated from ATLL patients were grown in vitro $[28,38]$. This might be linked to a high expression of the IL-4 receptor (IL-4R), especially, at the surface of cells from acute ATLL patients [39]. IL-4 is undetectable in culture supernatants obtained from ATLL cells or in the supernatant from ATLL cells, before or after stimulation $[38,40]$. These results suggest that the HTLV-1 infection is not enough to maintain the IL-4 production and IL-4-induced proliferation. However, one cannot exclude that in vivo proliferation of the infected T-cells occurs within lymphoid organs, in which even low levels of IL-4 could act in an autocrine or paracrine manner.

IL-4 production may not be necessary to sustain the infected cell proliferation, if a constitutive IL-4 signaling is activated. Indeed, IRF-4 (Interferon Regulatory Factor 4) upregulation [41], could compensate the lack of IL-4 production by the HTLV-1-infected T-cells. Although Tax is sufficient to upregulate the IRF-4 expression, leukemic cells are able to express IRF-4 in the absence of any Tax expression [42]. This is likely to be the consequence of, both, amplification and of point mutations in the irf4 gene. This results in gain-of-function mutations within the DNA-binding domain of the protein [43]. Among them, K59R point mutation in irf4, which is commonly found in ATLL patients, leads to the expression of a more active IRF4 protein [44]. In addition, activation of the IRF4 could be driven by HBZ [37], whose expression is maintained in the ATLL cells [45]. Interestingly, HBZ did not directly induce the IRF4 expression but had an effect on the BATF3, the partner of IRF4 that is involved in regulation of a series of BATF3/IRF4-targeted genes that control cell proliferation and cell survival [37].

HAM/TSP patients are characterized by high IL-4 level in the serum [46] and an increased frequency of IL-4 expressing PBMCs [47], compared to asymptomatic carriers and healthy donors. In contrast, IL-4 expression within the CD4+ CD25+ CCR4+ (CC chemokine Receptor 4) T-cells, which is the phenotype of the HTLV-1-infected T-cells, is lower in the HAM/TSP patients, compared to healthy donors. This suggests that IL-4 is mainly expressed in other cell types, and could act in a paracrine manner to induce the proliferation of the HTLV-1-infected cells.

Finally, IL-4 could also be compensated by IL-13, since both cytokines signal through a complex receptor composed of IL-4R and IL-13R [48]. Interestingly, IL-13R is also upregulated in HTLV-1-infected cells [49]. Furthermore, IL-13 mRNA is highly expressed in the HTLV-1-infected $\mathrm{CD} 4+$ and $\mathrm{CD} 8+$ cell lines, and its expression is upregulated by the Tax protein, through NF-KB activation [50,51]. 


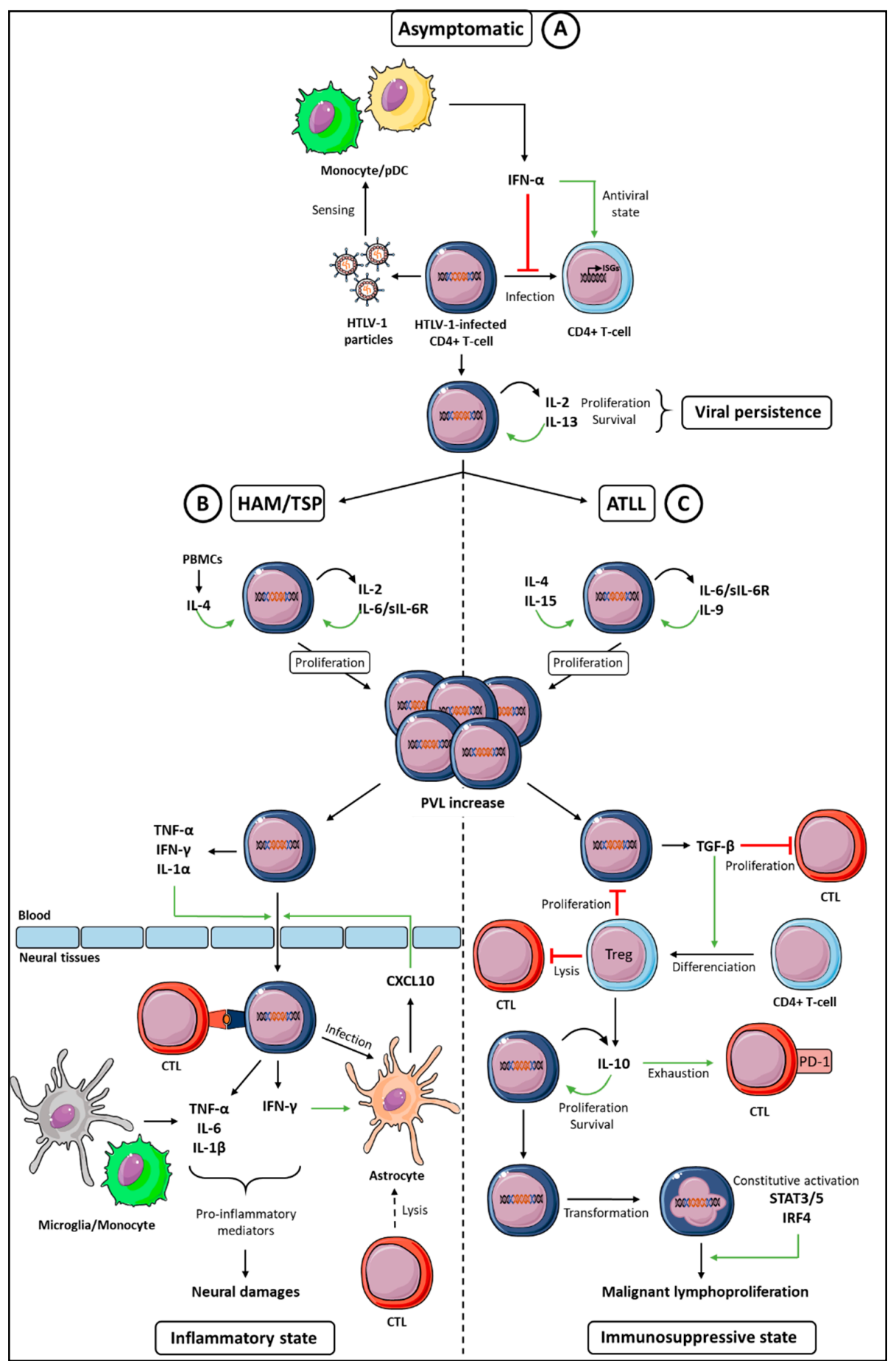

Figure 1. Global cytokine networks dysregulation during an HTLV-1 infection and HTLV-1-associated diseases. Three classes of cytokines can be involved in HTLV-1 persistence and diseases. (A) During the asymptomatic period that follows primo infection (top), IFN- $\alpha$, IL-2, and IL-13 ensure, respectively, the antiviral control and proliferation of infected cells, both effects allowing viral persistence. (B) During the HAM/TSP disease (left), proinflammatory cytokines (IFN- $\gamma$, IL-1, TNF- $\alpha$, and CXCL10) allow infiltration of the HTLV-1-infected T-cells in neural tissues that, in addition with IL-6, contribute to the chronic inflammatory state and neural damages. (C) During ATLL (right), immunosuppressive cytokines (TGF- $\beta$ and IL-10) contribute to Cytotoxic T Lymphocytes (CTL) exhaustion, allowing an immunosuppressive state favorable to the malignant proliferation of HTLV-1-transformed cells. Green arrows indicate an increased function, red lines indicate a decreased function, and the curved arrow indicate autocrine proliferation. See text for details. 


\subsection{IL-6}

IL-6-serum concentrations are higher in ATLL patients and HAM/TSP patients, compared to the levels observed both in asymptomatic carriers and healthy individuals [52,53]. IL-6 levels correlate with ATLL aggressiveness and a shorter survival rate [54]. IL-6 increase could result from its production by the HTLV-1-infected cells, themselves, since ATLL or HAM/TSP-derived IL-2-dependent T-cell lines, as well as CD8+ T cells or monocytes [55], are able to express IL-6 [56]. Tax expression from the HTLV-1-infected cell lines is required to induce IL-6R expression [57]. In addition, Tax also promotes the release of a soluble form of IL-6R (sIL-6R), whose level increases in the ATLL and HAM/TSP patients sera [57]. IL-6/sIL-6R complex can activate cells through their interaction with gp130, the IL-6 co-receptor [58]. Finally, IL-6 or IL-6/sIL-6R binding may also be dispensable, since constitutive activation of the STAT3, the downstream effector of IL-6 signaling, has been reported in the HTLV-1 transformed cell lines [57].

\section{Paradoxical Functions of the IFN-I Antiviral Cytokine}

The first cytokines to be induced, following a viral infection are those of innate immunity, including type I interferons (IFN-I), which have antiviral functions. The IFN-I family comprises several members-13 IFN- $\alpha$ subtypes, 1 IFN- $\beta$ subtype, and less characterized cytokines, such as IFN- $\varepsilon,-\delta,-\kappa$, $-\tau,-\omega$ et $-\zeta$ [59]. IFN- $\alpha$ and $-\beta$ production is induced through virus recognition by specific receptors that trigger a signaling cascade ending with the activation of IRF3 and IRF7 transcription factors [60]. Then, binding of IFN-I members to their receptor (IFNAR) and signaling through JAK/STAT [61] induces the expression of several ISGs (Interferon Stimulated Genes), with different antiviral functions [62].

The functions of IFN-I during HTLV-1 infection are not completely understood [63,64]. However, its use for therapy argues for a beneficial role, since a combination of IFN- $\alpha$ with zidovudine has better effect than classical chemotherapy, when provided to ATLL patients, except for those suffering from the lymphoma subtype [65]. Similarly, treatment of the HAM/TSP patients, with exogenous IFN-I, is associated with improvement of clinical symptoms [66-69] and with an inhibition of the T-cells' spontaneous proliferation, as well as with a decrease in viral genes expression [70,71]. Nevertheless, how IFN-I promotes HTLV-1 control, in vivo, is still poorly understood. In vitro, recombinant IFN- $\alpha$ inhibits the infection by HTLV-1 of PBMCs, CBMCs (Cord Blood Mononuclear Cells), primary T-cells, and Jurkat T-cells [72,73], in a dose-dependent manner, notably through the expression of the ISG PKR (Protein Kinase R). This leads to a decrease in the HTLV-1 proteins expression and to the release of HTLV-1 particles by the newly infected T-cells [73,74]. Interestingly, IFN-I treatment of dendritic cells does not prevent their infection by HTLV-1 [3]. This suggests that the IFN-I-mediated control of HTLV-1 infection might be cell-type dependent. In contrast, the IFN- $\alpha$ treatment of the HTLV-1 transformed T-cell lines does not induce a reduction of viral proteins expression [74], suggesting that other ISGs can compete with PKR, or that the IFN-I response is inefficient when chronic infection is established. Indeed, the ISG ADAR1 (Adenosine Deaminase Acting on RNA 1) was shown to have a proviral role, by counteracting the PKR function [75], while the IFN-I signaling is abolished in the HTLV-1-infected cells [76-78] and the Tax-expressing cells [79].

Dysregulation of the IFN-I signaling does not seem to be associated with a decrease in cell surface expression of IFNAR in the HTLV-1-infected T-cells [78], but to an inhibition of JAK/STAT proteins phosphorylation $[76,77,80]$. This could partly be associated to the Tax-dependent upregulation of SOCS1 (Suppressor of Cytokine Signaling 1) [77,79], a known negative-regulator of the IFN-I signalization [62]. In addition, inhibition of IFN-I signaling might result from the inhibition of the transcriptional activity of the STAT proteins [68]. As reported for other viral infections [81], HTLV-1 infection is also expected to control the IFN-I production in infected T-cells. Nevertheless, how IFN-I response is induced or regulated during the HTLV-1 infection is still poorly understood. Tax abrogates IRF7 phosphorylation and transcriptional functions [82,83], but its effect on the IRF3 activation is more controversial. While some studies showed that Tax blocks the IRF3 phosphorylation and, thus, its transcriptional activity $[77,82,84,85]$, others suggested a Tax-dependent induction of IRF3 
phosphorylation, thus, enhancing its activity $[86,87]$. These discrepancies are likely linked to the different levels of Tax expression, in the different cellular models used in these studies.

If HTLV-1 infection can impact IFN-I production and signaling, this virus can also be recognized by several sensors, such as STING (Stimulator of Interferon Genes), IFI16 (Interferon- $\gamma$ Inducible protein 16), and Ku70 [88-90], in the infected cells and by TLR-7 in plasmacytoid dendritic cells [91], which leads to the induction of IFN-I production, thus, potentially contributing to the HTLV-1 infection control. However, it is worth noting that the ATLL and HAM/TSP patients present a depletion of plasmacytoid dendritic cells [92-94], further supporting the role of IFN-I in the control of the HTLV-1 infection. While the PBMCs from the ATLL patients have a decreased ability to produce IFN-I, after triggering [92], a higher IFN-I signature is observed in the HAM/TSP patients, but not in the asymptomatic carriers [71]. This suggests that IFN-I response might be related to pathogenesis. Although IFN-I seems efficient to control the viral replication in vitro and to treat some HTLV-1 induced symptoms in vivo, the precise mode of action of this cytokine, as well as how and whether it could be induced in patients, needs further investigations.

\section{Cytokines Promoting the HTLV-1-Induced Diseases Development}

\subsection{Cytokine Signature in HAM-TSP}

Compared to healthy donors or asymptomatic carriers, the HAM/TSP patients are characterized by elevated levels of pro-inflammatory cytokines, such as IL-4, IL-6, IL-8, IFN- $\gamma$, and TNF- $\alpha$ (Tumor Necrosis Factor- $\alpha$ ) in their plasma $[95,96]$. T-cells from the HAM/TSP patients spontaneously express IFN- $\gamma$, TNF- $\alpha$, IL-6, and IL-1 $\beta$ [56,97], whose increased levels in the CSF [98] has been suggested to promote inflammatory immune responses in the HAM/TSP patients [99] (Figure 1B). Among these cytokines, IFN- $\gamma$ has been described as the main driver for the induction of inflammation. It is worth noting that the HAM/TSP patients are characterized by an elevated IFN signature [71]. Thus, a chronic IFN- $\gamma$-stimulation of the immune cells, including the CTLs (cytotoxic T-cells) in vivo, could be deleterious for neural tissues [11,17].

In addition, IFN- $\gamma$ favors the CD4+ T-cells migration, from blood to the central nervous system (CNS) [100], a characteristic of the HAM/TSP patients [101]. In addition, T-cells infiltration in the CNS might be increased because of permeability changes of the blood-brain barrier, due to tight junctions disruption between the human brain endothelial cells. This is induced either by the IL-1 $\alpha$ and the TNF- $\alpha$ cytokines secreted by the HTLV-1-infected T-cells [102], or after the HTLV-1 endothelial cells infection [103]. Infiltration of the HTLV-1-infected CD4+ T-cells and CD8+ T-cells in neural tissues and in the CSF $[14,15]$ leads to an increased proviral load (PVL) in the CSF, compared to the blood compartment [16]. This contributes to demyelination events within the CNS [17] (Figure 1B).

Other pro-inflammatory mediators, such as MIP- $1 \alpha$ (Macrophage inflammatory protein-1 $\alpha$ ) and RANTES (Regulated on Activation, Normal T-cell Expressed and Secreted), are spontaneously produced by the PBMCs obtained from the HAM/TSP and could further contribute to the global inflammation process [104]. Of note, elevated serum levels of the immunomodulator IL-10 have also been observed in the HAM/TSP patients [55]. In contrast, in the asymptomatic carriers, IL-10 expressing CTL might counterbalance the induced-inflammation linked to the TNF- $\alpha$ production by monocytes. This effect is lost in the HAM/TSP patients, probably because of an increased IFN- $\gamma$-expressing CTL frequency [105]. Correction of the immunological imbalance with IL-10 up regulation has been observed in HAM/TSP patients, upon therapeutic intervention. This was correlated with clinical improvement [106].

Finally, elevated levels of neopterin in the plasma and the CSF of the HAM/TSP patients [107] could contribute to the neurotoxic events occurring in these patients, since the CSF-associated neopterin levels positively correlate to the severity of the clinical symptoms $[108,109]$. 


\subsection{The Interplay between IFN- $\gamma$ and CXCL10 in the Model of the HAM/TSP Development}

Once infiltrated in the CNS, IFN- $\gamma$-producing HTLV-1-infected CD4+ T-cells induce CXCL10 (C-X-C motif chemokine Ligand 10) production by the astrocytes [101,110]. Probably linked to this, CXCL9 and CXCL10 concentrations are elevated in the HAM/TSP patients [95,111]. CXCL9 and CXCL10 associated levels in the CSF, correlate with the disease progression [109] and the PVL values [111]. Consequently, these two chemokines have been proposed to be markers of the HAM/TSP severity [109]. CXCL9 and CXCL10 are chemokines that are able to recruit the CXCR3 (C-X-C chemokine Receptor 3) expressing cells. CXCR3 is expressed by the IFN- $\gamma$ producing CD4+ T-cells [112]. Thus, CXCL9 and CXCL10 expression promotes the positive feedback loop of the CXCR3+ T-cells recruitment in neural tissues, resulting in the maintenance of CNS chronic inflammation [101] (Figure 1B).

Astrocytes from the HAM/TSP patients constitute the cellular targets of HTLV-1 infections in vivo $[113,114]$. As such, through the expression of viral proteins, and specially Tax, they may be targeted by the HTLV-1-specific CTLs, and this could exacerbate the neural tissue damages [115,116]. Finally, Tax expression in astroglioma or astrocytoma cells leads to the expression of several pro-inflammatory cytokines, such as TNF- $\alpha$, IL-1 $\alpha$, IL-1 $\beta$, and IL-6 [117]. It has been suggested that secretion of these cytokines by microglia cells or monocytes could contribute to the HAM/TSP pathogenesis.

\section{Cytokine Signature in ATLL}

\subsection{Low IFN- $\gamma$ Expression}

IFN- $\gamma$ expression has been reported in some HTLV-1-infected T-cell lines $[40,56,118,119]$. It seems to be associated with Tax expression $[120,121]$. However, downregulation of Tax expression in vivo, and especially in leukemic cells [122], correlates with the lack of IFN- $\gamma$ expression in CD4+ T-cells, freshly isolated from these patients [97]. This lack of IFN- $\gamma$ production seems, therefore, likely linked to ATLL development, a hypothesis further supported by the observation that Tax-transgenic mice deficient of the IFN- $\gamma$ expression, develop tumors [123]. This lower IFN- $\gamma$ production could be associated with a decreased functionality of the CTLs, in combination with the elevated levels of IL-10, as described below (Figure 1C).

\subsection{TGF- $\beta$ Expression and Treg Development}

In vitro culture of fresh ATLL cells and long-term ATLL T-cell lines, constitutively express TGF- $\beta$ (Transforming Growth Factor- $\beta$ ) mRNA and secrete TGF- $\beta$ [97,124,125], although TGF- $\beta$ levels in the serum of ATLL patients are not significantly different from that of healthy donors [53]. Surprisingly, the TGF- $\beta$, known as an inhibitor of cell proliferation [126], does not prevent the spontaneous proliferation of the HTLV-1-infected T-cells [127]. While Tax is able to induce TGF- $\beta$ production, by activating its gene promoter [124], several studies have also reported that Tax inhibits the TGF- $\beta$ signaling, through reduction of the TGF- $\beta$ receptor II expression, of Smad3/4 complex formation and its DNA binding on the TGF- $\beta$ responsive elements, as well as of the recruitment of p300 by Smad proteins [128-131]. In contrast, HBZ overcomes the negative impact of Tax on the TGF- $\beta$ signaling by favoring Smad 3 and p300 interactions [132]. This could recapitulate an intact TGF- $\beta$ signaling in leukemic cells, in which Tax expression is frequently silenced [133].

Apart from regulating cells proliferation, TGF- $\beta$ signaling induces Foxp3 expression in peripheral CD4+ T-cells [134] and promotes regulatory T-cells responses. Interestingly, ATLL patients have a number of blood-circulating Foxp3+ CD4+ T-cells, higher than healthy donors [135,136]. Furthermore, a positive correlation between Foxp3+ CD4+ T-cells frequency, among the PBMCs and the CCL22 plasmatic levels, has been reported in the asymptomatic carriers and in chronic ATLL patients [136]. This cytokine induces the Foxp3+ CD4+ T-cells migration and sustains their viability [136]. These cells, obtained from patients with acute or chronic ATLL, are able to inhibit the CD4+ CD25+ T-cells 
autologous proliferation. They also decrease the rate of CTL-dependent lysis of the autologous Tax+ CD4+ T-cells [137]. Defining the Treg function in ATLL pathogenesis, therefore, remains delicate. On one hand, Treg may limit ATLL development by inhibiting leukemic cells proliferation. On the other hand, Treg could inhibit the rate of the infected T-cells lysis by the CD8+ T-cells, thus, contributing to the escape of the HTLV-1-infected cells from adaptive immune responses.

\subsection{IL-10 and T-Cell Exhaustion}

Sera from ATLL patients contain increased levels of IL-10, compared to the asymptomatic carriers, the HAM/TSP patients, or the healthy donors [53,55,138]. Interestingly, IL-10 levels are even higher in patients with the aggressive subtypes of ATLL, than in patients with indolent ATLL, therefore, associating IL-10 levels to a poor prognosis [53,138]. HTLV-1-infected T-cell lines and freshly isolated ATLL cells are also able to release IL-10 in the supernatant $[39,56,139]$, and the absolute frequency of IL-10 producing cells is higher in the ATLL patients, than in the asymptomatic carriers [138]. IL-10 expression is induced by Tax or HBZ [138,140]. IL-10 promotes cell survival, cell proliferation, and even IL-10 production in an autocrine/paracrine manner [56]. In ATLL patients, high levels of IL-10 have been associated with the malignant proliferation of HTLV-1-infected cells [55]. Along with the HTLV-1-infected CD4+ T-cells, IL-10 could also be expressed by the HTLV-1-infected macrophages [141], dendritic cells [140], or Treg [142], whose levels are increased in ATLL patients.

IL-10 has been reported to contribute to the immune escape of several other viruses and to deplete the CD8+ T-cell responses [143], notably, through the induction of the exhaustion marker PD-1 on T-cells [144]. Frequencies of the PD-1 expressing CD4+ and CD8+ T-cells are increased in the ATLL patients $[145,146]$. Furthermore, in asymptomatic carriers, PD-1+ Tax-specific CTLs frequency positively correlates with the HTLV-1 proviral load (PVL) in the PBMCs, and inversely, with the production of IFN- $\gamma$ and TNF- $\alpha$, after their stimulation with cognate peptides [147]. These results could be associated to the decreased frequency, diversity, and function of the anti-HTLV-1 Tax-specific CD8+ T-cells observed in the ATLL patients, and could favor the ATLL pathogenesis [148]. Indeed, interfering with the PD-1 triggering, enhances the IFN- $\gamma$ and TNF- $\alpha$ production by the HTLV-1 specific CD8+ T-cells [145]. High serum IL-10 level has also been observed in HAM/TSP patients [55], although PD-1 expression on the CTLs from the HAM/TSP patients has not been reported, yet. In addition to an increased ratio of the $\mathrm{CD} 8^{+} \mathrm{IFN}-\gamma^{+} / \mathrm{CD} 8^{+} \mathrm{IL}-10^{+} \mathrm{T}$-cells in the HAM/TSP, the immunosuppressive effect of IL-10 could also be counterbalanced by the elevated levels of the IFN- $\gamma$ in the CSF, from the HAM/TSP patients.

\section{Conclusions}

Cytokine network supporting viral persistence and eventually viral-induced diseases is summarized in Figure 1. Several interleukins are involved in the HTLV-1-infected T-cells proliferation and survival, thus, contributing to viral persistence in infected individuals. Alterations of cytokines signaling, within the HTLV-1-transformed T-cells, lead to a cytokine-independent growth, which could partly contribute to the ATLL development. Furthermore, viral persistence could be enhanced by the HTLV-1 properties to dysregulate the early IFN-I responses, in vivo. Dysregulation of the immune cytokine networks in the HAM/TSP and ATLL patients, is characterized by an exacerbated expression of the pro-inflammatory or immunosuppressive cytokines, respectively, which have detrimental effects on overall immune responses. In addition to the elevated levels of these cytokines in the fluids of patients, it is more likely that direct dysregulations of the balance between functionally opposite cytokines, such as IFN- $\gamma /$ IL-10 balance, contributes to the pathogenesis [96,149]. A complex network of cytokines could first generate a microenvironment, advantageous to the persistence of the HTLV-1-infected cells and, then, could contribute to the HTLV-1-induced diseases development.

Author Contributions: H.D. and J.C. conceived the work. N.F., R.M., and H.D. wrote the main manuscript. G.P., and J.C. reviewed the manuscript. All authors accepted the final version of this manuscript. 
Funding: This work was supported by the "Ligue Nationale contre le Cancer, équipe labélisée program" EL2013-3Mahieux to H.D. and R.M., by the LabEx Ecofect (ANR-11-LABX-0048) of the "Université de Lyon" to R.M., and by the Conselho Nacional de Pesquisa Tecnológico (CNP) Award to J.C. (CNPq 301685/2016-9) and by FAPESP (Fundação de Amparo à Pesquisa do Estado de São Paulo-n. 2014/22827-7) to J.C. N.F. acknowledge the "Ligue contre le Cancer" for his PhD fellowship and G.P. thanks the CNPq for her scholarship 133783/2018-9. H.D. thanks the "Soroptimist groupe de l'Ariège" for their financial gift. R.M. thanks ENS-Lyon for its support.

Conflicts of Interest: The authors declare no conflicts of interest.

\section{References}

1. Futsch, N.; Mahieux, R.; Dutartre, H. HTLV-1, the Other Pathogenic Yet Neglected Human Retrovirus: From Transmission to Therapeutic Treatment. Viruses 2017, 10, 1. [CrossRef] [PubMed]

2. Bangham, C.R.; Cook, L.B.; Melamed, A. HTLV-1 clonality in adult T-cell leukaemia and non-malignant HTLV-1 infection. Semin. Cancer Biol. 2014, 26, 89-98. [CrossRef] [PubMed]

3. Rizkallah, G.; Alais, S.; Futsch, N.; Tanaka, Y.; Journo, C.; Mahieux, R.; Dutartre, H. Dendritic cell maturation, but not type I interferon exposure, restricts infection by HTLV-1, and viral transmission to T-cells. PLoS Pathog. 2017, 13, e1006353. [CrossRef]

4. Furuta, R.; Yasunaga, J.I.; Miura, M.; Sugata, K.; Saito, A.; Akari, H.; Ueno, T.; Takenouchi, N.; Fujisawa, J.I.; Koh, K.R.; et al. Human T-cell leukemia virus type 1 infects multiple lineage hematopoietic cells in vivo. PLoS Pathog. 2017, 13, e1006722. [CrossRef] [PubMed]

5. Kannian, P.; Yin, H.; Doueiri, R.; Lairmore, M.D.; Fernandez, S.; Green, P.L. Distinct Transformation Tropism Exhibited by Human T Lymphotropic Virus Type 1 (HTLV-1) and HTLV-2 Is the Result of Postinfection T Cell Clonal Expansion. J. Virol. 2012, 86, 3757-3766. [CrossRef] [PubMed]

6. Jones, K.S.; Petrow-Sadowski, C.; Huang, Y.K.; Bertolette, D.C.; Ruscetti, F.W. Cell-free HTLV-1 infects dendritic cells leading to transmission and transformation of CD4(+) T cells. Nat. Med. 2008, 14, 429-436. [CrossRef] [PubMed]

7. Alais, S.; Mahieux, R.; Dutartre, H. Viral Source-Independent High Susceptibility of Dendritic Cells to Human T-Cell Leukemia Virus Type 1 Infection Compared to That of T Lymphocytes. J. Virol. 2015, 89, 10580-10590. [CrossRef]

8. Gessain, A.; Cassar, O. Epidemiological Aspects and World Distribution of HTLV-1 Infection. Front. Microbiol. 2012, 3, 388. [CrossRef]

9. Tsukasaki, K.; Tobinai, K. Clinical Trials and Treatment of ATL. Leuk. Res. Treat. 2012, 2012, 101754. [CrossRef]

10. Osame, M.; Janssen, R.; Kubota, H.; Nishitani, H.; Igata, A.; Nagataki, S.; Mori, M.; Goto, I.; Shimabukuro, H.; Khabbaz, R.; et al. Nationwide survey of HTLV-I-associated myelopathy in Japan: Association with blood transfusion. Ann. Neurol. 1990, 28, 50-56. [CrossRef]

11. Bangham, C.R.; Araujo, A.; Yamano, Y.; Taylor, G.P. HTLV-1-associated myelopathy/tropical spastic paraparesis. Nat. Rev. Dis. Primers 2015, 1, 15012. [CrossRef] [PubMed]

12. Hodson, A.; Laydon, D.J.; Bain, B.J.; Fields, P.A.; Taylor, G.P. Pre-morbid human T-lymphotropic virus type I proviral load, rather than percentage of abnormal lymphocytes, is associated with an increased risk of aggressive adult T-cell leukemia/lymphoma. Haematologica 2013, 98, 385-388. [CrossRef] [PubMed]

13. Oliveira, P.D.; Kachimarek, A.C.; Bittencourt, A.L. Early Onset of HTLV-1 Associated Myelopathy/Tropical Spastic Paraparesis (HAM/TSP) and Adult T-cell Leukemia/Lymphoma (ATL): Systematic Search and Review. J. Trop. Pediatr. 2018, 64, 151-161. [CrossRef] [PubMed]

14. Umehara, F.; Izumo, S.; Nakagawa, M.; Ronquillo, A.T.; Takahashi, K.; Matsumuro, K.; Sato, E.; Osame, M. Immunocytochemical analysis of the cellular infiltrate in the spinal cord lesions in HTLV-I-associated myelopathy. J. Neuropathol. Exp. Neurol. 1993, 52, 424-430. [CrossRef] [PubMed]

15. Kubota, R.; Soldan, S.S.; Martin, R.; Jacobson, S. Selected cytotoxic T lymphocytes with high specificity for HTLV-I in cerebrospinal fluid from a HAM/TSP patient. J. Neurovirol. 2002, 8, 53-57. [CrossRef] [PubMed]

16. Nagai, M.; Yamano, Y.; Brennan, M.B.; Mora, C.A.; Jacobson, S. Increased HTLV-I proviral load and preferential expansion of HTLV-I Tax-specific CD8+ T cells in cerebrospinal fluid from patients with HAM/TSP. Ann. Neurol. 2001, 50, 807-812. [CrossRef] [PubMed]

17. Matsuura, E.; Kubota, R.; Tanaka, Y.; Takashima, H.; Izumo, S. Visualization of HTLV-1-Specific Cytotoxic T Lymphocytes in the Spinal Cords of Patients With HTLV-1-Associated Myelopathy/Tropical Spastic Paraparesis. J. Neuropathol. Exp. Neurol. 2015, 74, 2-14. [CrossRef] 
18. Shimoyama, M. Diagnostic criteria and classification of clinical subtypes of adult T-cell leukaemia-lymphoma. A report from the Lymphoma Study Group (1984-87). Br. J. Haematol. 1991, 79, 428-437. [CrossRef]

19. Enose-Akahata, Y.; Vellucci, A.; Jacobson, S. Role of HTLV-1 Tax and HBZ in the Pathogenesis of HAM/TSP. Front. Microbiol. 2017, 8, 2563. [CrossRef]

20. Giam, C.-Z.; Semmes, O.J. HTLV-1 Infection and Adult T-Cell Leukemia/Lymphoma-A Tale of Two Proteins: Tax and HBZ. Viruses 2016, 8, 161. [CrossRef]

21. Arenas-Ramirez, N.; Woytschak, J.; Boyman, O. Interleukin-2: Biology, Design and Application. Trends Immunol. 2015, 36, 763-777. [CrossRef]

22. Leung, K.; Nabel, G.J. HTLV-1 transactivator induces interleukin-2 receptor expression through an NF-kB-like factor. Nature 1988, 333, 776-778. [CrossRef] [PubMed]

23. Tendler, C.L.; Greenberg, S.J.; Blattner, W.A.; Manns, A.; Murphy, E.; Fleisher, T.; Hanchard, B.; Morgan, O.; Burton, J.D.; Nelson, D.L. Transactivation of interleukin 2 and its receptor induces immune activation in human T-cell lymphotropic virus type I-associated myelopathy: Pathogenic implications and a rationale for immunotherapy. Proc. Natl. Acad. Sci. USA 1990, 87, 5218-5222. [CrossRef] [PubMed]

24. Itoyama, Y.; Minato, S.; Kira, J.; Goto, I.; Sato, H.; Okochi, K.; Yamamoto, N. Spontaneous proliferation of peripheral blood lymphocytes increased in patients with HTLV-I-associated myelopathy. Neurology 1988, 38, 1302-1307. [CrossRef]

25. Collins, N.D.; D’Souza, C.; Albrecht, B.; Robek, M.D.; Ratner, L.; Ding, W.; Green, P.L.; Lairmore, M.D. Proliferation Response to Interleukin-2 and Jak/Stat Activation of T Cells Immortalized by Human T-Cell Lymphotropic Virus Type 1 Is Independent of Open Reading Frame I Expression. J. Virol. 1999, 73, 9642-9649.

26. Hori, T.; Uchiyama, T.; Umadome, H.; Tamori, S.; Tsudo, M.; Araki, K.; Uchino, H. Dissociation of interleukin-2-mediated cell proliferation and interleukin-2 receptor upregulation in adult T-cell leukemia cells. Leuk. Res. 1986, 10, 1447-1453. [CrossRef]

27. Uchiyama, T.; Hori, T.; Tsudo, M.; Wano, Y.; Umadome, H.; Tamori, S.; Yodoi, J.; Maeda, M.; Sawami, H.; Uchino, H. Interleukin-2 receptor (Tac antigen) expressed on adult T cell leukemia cells. J. Clin. Investig. 1985, 76, 446-453. [CrossRef]

28. Uchiyama, T.; Kamio, M.; Kodaka, T.; Tamori, S.; Fukuhara, S.; Amakawa, R.; Uchino, H.; Araki, K. Leukemic cells from some adult T-cell leukemia patients proliferate in response to interleukin-4. Blood 1988, 72, 1182-1186. [PubMed]

29. Arya, S.K.; Wong-Staal, F.; Gallo, R.C. T-cell growth factor gene: Lack of expression in human T-cell leukemia-lymphoma virus-infected cells. Science 1984, 223, 1086-1087. [CrossRef] [PubMed]

30. Migone, T.S.; Lin, J.X.; Cereseto, A.; Mulloy, J.C.; O'Shea, J.J.; Franchini, G.; Leonard, W.J. Constitutively activated Jak-STAT pathway in T cells transformed with HTLV-I. Science 1995, 269, 79-81. [CrossRef] [PubMed]

31. Zhang, Q.; Lee, B.; Korecka, M.; Li, G.; Weyland, C.; Eck, S.; Gessain, A.; Arima, N.; Lessin, S.R.; Shaw, L.M.; et al. Differences in phosphorylation of the IL-2R associated JAK/STAT proteins between HTLV-I (+), IL-2-independent and IL-2-dependent cell lines and uncultured leukemic cells from patients with adult T-cell lymphoma/leukemia. Leuk. Res. 1999, 23, 373-384. [CrossRef]

32. Takemoto, S.; Mulloy, J.C.; Cereseto, A.; Migone, T.-S.; Patel, B.K.R.; Matsuoka, M.; Yamaguchi, K.; Takatsuki, K.; Kamihira, S.; White, J.D.; et al. Proliferation of adult T cell leukemia/lymphoma cells is associated with the constitutive activation of JAK/STAT proteins. Proc. Natl. Acad. Sci. USA 1997, 94, 13897-13902. [CrossRef]

33. Huey, D.D.; Bolon, B.; Perle, K.M.D.L.; Kannian, P.; Jacobson, S.; Ratner, L.; Green, P.L.; Niewiesk, S. Role of Wild-type and Recombinant Human T-cell Leukemia Viruses in Lymphoproliferative Disease in Humanized NSG Mice. Comp. Med. 2018, 68, 4-14.

34. Chen, J.; Petrus, M.; Bryant, B.R.; Nguyen, V.P.; Goldman, C.K.; Bamford, R.; Morris, J.C.; Janik, J.E.; Waldmann, T.A. Autocrine/paracrine cytokine stimulation of leukemic cell proliferation in smoldering and chronic adult T-cell leukemia. Blood 2010, 116, 5948-5956. [CrossRef]

35. Fung, M.M.; Chu, Y.-L.; Fink, J.L.; Wallace, A.; McGuire, K.L. IL-2- and STAT5-regulated cytokine gene expression in cells expressing the Tax protein of HTLV-1. Oncogene 2005, 24, 4624-4633. [CrossRef]

36. Yamada, Y.; Sugawara, K.; Hata, T.; Tsuruta, K.; Moriuchi, R.; Maeda, T.; Atogami, S.; Murata, K.; Fujimoto, K.; Kohno, T;; et al. Interleukin-15 (IL-15) Can Replace the IL-2 Signal in IL-2-Dependent Adult T-Cell Leukemia (ATL) Cell Lines: Expression of IL-15 Receptor $\alpha$ on ATL Cells. Blood 1998, 91, 4265-4272. 
37. Nakagawa, M.; Shaffer, A.L.; Ceribelli, M.; Zhang, M.; Wright, G.; Huang, D.W.; Xiao, W.; Powell, J.; Petrus, M.N.; Yang, Y.; et al. Targeting the HTLV-I-Regulated BATF3/IRF4 Transcriptional Network in Adult T Cell Leukemia/Lymphoma. Cancer Cell 2018, 34, 286-297.e10. [CrossRef]

38. Mori, N.; Yamashita, U.; Tanaka, Y.; Nakata, K.; Oda, S.; Morimoto, I.; Eto, S. Interleukin-4 induces proliferation of adult T-cell leukemia cells. Eur. J. Haematol. 1993, 50, 133-140. [CrossRef]

39. Mori, N.; Shirakawa, F.; Murakami, S.; Oda, S.; Eto, S. Characterization and regulation of interleukin-4 receptor in adult T-cell leukemia cells. Eur. J. Haematol. 1996, 56, 241-247. [CrossRef]

40. Yamada, Y.; Ohmoto, Y.; Hata, T.; Yamamura, M.; Murata, K.; Tsukasaki, K.; Kohno, T.; Chen, Y.; Kamihira, S.; Tomonaga, M. Features of the Cytokines Secreted by Adult T Cell Leukemia (ATL) Cells. Leuk. Lymphoma 1996, 21, 443-447. [CrossRef]

41. Gupta, S.; Jiang, M.; Anthony, A.; Pernis, A.B. Lineage-Specific Modulation of Interleukin 4 Signaling by Interferon Regulatory Factor 4. J. Exp. Med. 1999, 190, 1837-1848. [CrossRef]

42. Ramos, J.C.; Ruiz, P.; Ratner, L.; Reis, I.M.; Brites, C.; Pedroso, C.; Byrne, G.E.; Toomey, N.L.; Andela, V.; Harhaj, E.W.; et al. IRF-4 and c-Rel expression in antiviral-resistant adult T-cell leukemia/lymphoma. Blood 2007, 109, 3060-3068. [CrossRef]

43. Kataoka, K.; Nagata, Y.; Kitanaka, A.; Shiraishi, Y.; Shimamura, T.; Yasunaga, J.; Totoki, Y.; Chiba, K.; Sato-Otsubo, A.; Nagae, G.; et al. Integrated molecular analysis of adult T cell leukemia/lymphoma. Nat. Genet. 2015, 47, 1304-1315. [CrossRef]

44. Cherian, M.A.; Olson, S.; Sundaramoorthi, H.; Cates, K.; Cheng, X.; Harding, J.; Martens, A.; Challen, G.A.; Tyagi, M.; Ratner, L.; et al. An activating mutation of interferon regulatory factor 4 (IRF4) in adult T-cell leukemia. J. Biol. Chem. 2018, 293, 6844-6858. [CrossRef]

45. Matsuoka, M.; Jeang, K.T. Human T-cell leukaemia virus type 1 (HTLV-1) infectivity and cellular transformation. Nat. Rev. Cancer 2007, 7, 270-280. [CrossRef]

46. Starling, A.L.B.; Coelho-dos-Reis, J.G.A.; Peruhype-Magalhães, V.; Pascoal-Xavier, M.A.; Gonçalves, D.U.; Béla, S.R.; Lambertucci, J.R.; Labanca, L.; Pereira, S.R.S.; Teixeira-Carvalho, A.; et al. Immunological signature of the different clinical stages of the HTLV-1 infection: Establishing serum biomarkers for HTLV-1-associated disease morbidity. Biomarkers 2015, 20, 502-512. [CrossRef]

47. Furukawa, Y.; Saito, M.; Matsumoto, W.; Usuku, K.; Tanaka, Y.; Izumo, S.; Osame, M. Different Cytokine Production in Tax-Expressing Cells between Patients with Human T Cell Lymphotropic Virus Type I (HTLV-I)-Associated Myelopathy/Tropical Spastic Paraparesis and Asymptomatic HTLV-I Carriers. J. Infect. Dis. 2003, 187, 1116-1125. [CrossRef]

48. Wang, T.; Secombes, C.J. The evolution of IL-4 and IL-13 and their receptor subunits. Cytokine 2015, 75, 8-13. [CrossRef]

49. Wäldele, K.; Schneider, G.; Ruckes, T.; Grassmann, R. Interleukin-13 Overexpression by Tax Transactivation: A Potential Autocrine Stimulus in Human T-Cell Leukemia Virus-Infected Lymphocytes. J. Virol. 2004, 78, 6081-6090. [CrossRef]

50. Chung, H.-K.; Young, H.A.; Goon, P.K.C.; Heidecker, G.; Princler, G.L.; Shimozato, O.; Taylor, G.P.; Bangham, C.R.M.; Derse, D. Activation of interleukin-13 expression in T cells from HTLV-1-infected individuals and in chronically infected cell lines. Blood 2003, 102, 4130-4136. [CrossRef]

51. Silbermann, K.; Schneider, G.; Grassmann, R. Stimulation of interleukin-13 expression by human T-cell leukemia virus type 1 oncoprotein Tax via a dually active promoter element responsive to NF- $\mathrm{B}$ and NFAT. J. Gen. Virol. 2008, 89, 2788-2798. [CrossRef]

52. Nishimoto, N.; Yoshizaki, K.; Eiraku, N.; Machigashira, K.; Tagoh, H.; Ogata, A.; Kuritani, T.; Osame, M.; Kishimoto, T. Elevated levels of interleukin-6 in serum and cerebrospinal fluid of HTLV-I-associated myelopathy/tropical spastic paraparesis. J. Neurol. Sci. 1990, 97, 183-193. [CrossRef]

53. Inagaki, A.; Ishida, T.; Ishii, T.; Komatsu, H.; Iida, S.; Ding, J.; Yonekura, K.; Takeuchi, S.; Takatsuka, Y.; Utsunomiya, A.; et al. Clinical significance of serum Th1-, Th2- and regulatory T cells-associated cytokines in adult T-cell leukemia/lymphoma: High interleukin-5 and -10 levels are significant unfavorable prognostic factors. Int. J. Cancer 2006, 118, 3054-3061. [CrossRef]

54. Yamamura, M.; Yamada, Y.; Momita, S.; Kamihira, S.; Tomonaga, M. Circulating interleukin-6 levels are elevated in adult T-cell leukaemia/lymphoma patients and correlate with adverse clinical features and survival. Br. J. Haematol. 1998, 100, 129-134. [CrossRef] 
55. Kagdi, H.; Demontis, M.A.; Ramos, J.C.; Taylor, G.P. Switching and loss of cellular cytokine producing capacity characterize in vivo viral infection and malignant transformation in human T- lymphotropic virus type 1 infection. PLoS Pathog. 2018, 14, e1006861. [CrossRef]

56. Sawada, L.; Nagano, Y.; Hasegawa, A.; Kanai, H.; Nogami, K.; Ito, S.; Sato, T.; Yamano, Y.; Tanaka, Y.; Masuda, T.; et al. IL-10-mediated signals act as a switch for lymphoproliferation in Human T-cell leukemia virus type-1 infection by activating the STAT3 and IRF4 pathways. PLoS Pathog. 2017, 13, e1006597. [CrossRef]

57. Horiuchi, S.; Yamamoto, N.; Dewan, M.Z.; Takahashi, Y.; Yamashita, A.; Yoshida, T.; Nowell, M.A.; Richards, P.J.; Jones, S.A.; Yamamoto, N. Human T-cell leukemia virus type-I Tax induces expression of interleukin-6 receptor (IL-6R): Shedding of soluble IL-6R and activation of STAT3 signaling. Int. J. Cancer 2006, 119, 823-830. [CrossRef]

58. Rose-John, S.; Neurath, M.F. IL-6 trans-Signaling: The Heat Is On. Immunity 2004, 20, 2-4. [CrossRef]

59. McNab, F.; Mayer-Barber, K.; Sher, A.; Wack, A.; O'Garra, A. Type I interferons in infectious disease. Nat. Rev. Immunol. 2015, 15, 87-103. [CrossRef]

60. Brubaker, S.W.; Bonham, K.S.; Zanoni, I.; Kagan, J.C. Innate Immune Pattern Recognition: A Cell Biological Perspective. Annu. Rev. Immunol. 2015, 33, 257-290. [CrossRef]

61. Ivashkiv, L.B.; Donlin, L.T. Regulation of type I interferon responses. Nat. Rev. Immunol. 2014, 14, 36-49. [CrossRef]

62. Tomasello, E.; Pollet, E.; Vu Manh, T.-P.; Uzé, G.; Dalod, M. Harnessing Mechanistic Knowledge on Beneficial Versus Deleterious IFN-I Effects to Design Innovative Immunotherapies Targeting Cytokine Activity to Specific Cell Types. Front. Immunol. 2014, 5, 526. [CrossRef]

63. Journo, C.; Mahieux, R. HTLV-1 and innate immunity. Viruses 2011, 3, 1374-1394. [CrossRef]

64. Kannagi, M.; Hasegawa, A.; Kinpara, S.; Shimizu, Y.; Takamori, A.; Utsunomiya, A. Double control systems for human T-cell leukemia virus type 1 by innate and acquired immunity. Cancer Sci. 2011, 102, 670-676. [CrossRef]

65. Bazarbachi, A.; Plumelle, Y.; Carlos Ramos, J.; Tortevoye, P.; Otrock, Z.; Taylor, G.; Gessain, A.; Harrington, W.; Panelatti, G.; Hermine, O. Meta-analysis on the use of zidovudine and interferon-alfa in adult T-cell leukemia/lymphoma showing improved survival in the leukemic subtypes. J. Clin. Oncol. 2010, 28, 4177-4183. [CrossRef]

66. Kuroda, Y.; Kurohara, K.; Fujiyama, F.; Takashima, H.; Endo, C.; Matsui, M.; Neshige, R.; Kakigi, R. Systemic interferon- $\alpha$ in the treatment of HTLV-I-associated myelopathy. Acta Neurol. Scand. 1992, 86, 82-86. [CrossRef]

67. Nakamura, T.; Shibayama, K.; Nagasato, K.; Matsuo, H.; Tsujihata, M.; Nagataki, S. The efficacy of interferon- $\alpha$ treatment in human T-lymphotropic virus type-I-associated myelopathy. Jpn. J. Med. 1990, 29, 362-367. [CrossRef]

68. Yamasaki, K.; Kira, J.; Koyanagi, Y.; Kawano, Y.; Miyano-Kurosaki, N.; Nakamura, M.; Baba, E.; Suzuki, J.; Yamamoto, A.; Yamamoto, N.; et al. Long-term, high dose interferon- $\alpha$ treatment in HTLV-I-associated myelopathy/tropical spastic paraparesis: A combined clinical, virological and immunological study. J. Neurol. Sci. 1997, 147, 135-144. [CrossRef]

69. Rafatpanah, H.; Rezaee, A.; Etemadi, M.M.; Hosseini, R.F.; Khorram, B.; Afsahr, L.; Taylor, G.; Mokhber, N.; Mahmoudi, M.; Abbaszadegan, M.R.; et al. The impact of interferon- $\alpha$ treatment on clinical and immunovirological aspects of HTLV-1-associated myelopathy in northeast of Iran. J. Neuroimmunol. 2012, 250, 87-93. [CrossRef]

70. Ijichi, S.; Izumo, S.; Nagai, M.; Shinmyozu, K.; Hall, W.W. Osame, mitsuhiro Anti-viral and immunomodulatory effects of interferon- $\alpha$ on cultured lymphocytes from patients with human $\mathrm{T}$ lymphotropic virus type I-associated myelopathy (HAM/TSP). J. Neuroimmunol. 1995, 61, $213-221$. [CrossRef]

71. Tattermusch, S.; Skinner, J.A.; Chaussabel, D.; Banchereau, J.; Berry, M.P.; McNab, F.W.; O'Garra, A.; Taylor, G.P.; Bangham, C.R. Systems biology approaches reveal a specific interferon-inducible signature in HTLV-1 associated myelopathy. PLoS Pathog. 2012, 8, e1002480. [CrossRef]

72. Macchi, B.; D'Onofrio, C.; Labianca, R.A.; Bonmassar, E. Mononuclear cells from peripheral blood of adult donors and from cord blood are equally protected by $\alpha$ - and $\beta$-interferons against infection with HTLV-I. Pharmacol. Res. 1990, 22, 503-514. [CrossRef] 
73. Cachat, A.; Chevalier, S.A.; Alais, S.; Ko, N.L.; Ratner, L.; Journo, C.; Dutartre, H.; Mahieux, R. Alpha interferon restricts human T-lymphotropic virus type 1 and 2 de novo infection through PKR activation. J. Virol. 2013, 87, 13386-13396. [CrossRef]

74. Kinpara, S.; Kijiyama, M.; Takamori, A.; Hasegawa, A.; Sasada, A.; Masuda, T.; Tanaka, Y.; Utsunomiya, A.; Kannagi, M. Interferon- $\alpha$ (IFN- $\alpha$ ) suppresses HTLV-1 gene expression and cell cycling, while IFN- $\alpha$ combined with zidovudine induces p53 signaling and apoptosis in HTLV-1-infected cells. Retrovirology 2013, 10, 52. [CrossRef]

75. Cachat, A.; Alais, S.; Chevalier, S.A.; Journo, C.; Fusil, F.; Dutartre, H.; Boniface, A.; Ko, N.L.; Gessain, A.; Cosset, F.L.; et al. ADAR1 enhances HTLV-1 and HTLV-2 replication through inhibition of PKR activity. Retrovirology 2014, 11, 93. [CrossRef]

76. Feng, X.; Ratner, L. Human T-cell leukemia virus type 1 blunts signaling by interferon $\alpha$. Virology 2008, 374, 210-216. [CrossRef]

77. Oliere, S.; Hernandez, E.; Lezin, A.; Arguello, M.; Douville, R.; Nguyen, T.L.; Olindo, S.; Panelatti, G.; Kazanji, M.; Wilkinson, P.; et al. HTLV-1 evades type I interferon antiviral signaling by inducing the suppressor of cytokine signaling 1 (SOCS1). PLoS Pathog. 2010, 6, e1001177. [CrossRef]

78. Smith, D.; Buckle, G.J.; Hafler, D.A.; Frank, D.A.; Hollsberg, P. HTLV-I-infected T cells evade the antiproliferative action of IFN- $\beta$. Virology 1999, 257, 314-321. [CrossRef]

79. Charoenthongtrakul, S.; Zhou, Q.; Shembade, N.; Harhaj, N.S.; Harhaj, E.W. Human T cell leukemia virus type 1 Tax inhibits innate antiviral signaling via NF-kappaB-dependent induction of SOCS1. J. Virol. 2011, 85, 6955-6962. [CrossRef]

80. Zhang, J.; Yamada, O.; Kawagishi, K.; Araki, H.; Yamaoka, S.; Hattori, T.; Shimotohno, K. Human T-cell leukemia virus type 1 Tax modulates interferon- $\alpha$ signal transduction through competitive usage of the coactivator CBP/p300. Virology 2008, 379, 306-313. [CrossRef]

81. Haller, O.; Kochs, G.; Weber, F. The interferon response circuit: Induction and suppression by pathogenic viruses. Virology 2006, 344, 119-130. [CrossRef] [PubMed]

82. Narulla, M.S.; Alsairi, A.; Charmier, L.; Noonan, S.; Conroy, D.; Hall, W.W.; Sheehy, N. Positive and Negative Regulation of Type I Interferons by the Human T Cell Leukemia Virus Antisense Protein HBZ. J. Virol. 2017, 91, e00853-17. [CrossRef] [PubMed]

83. Hyun, J.; Ramos, J.C.; Toomey, N.; Balachandran, S.; Lavorgna, A.; Harhaj, E.; Barber, G.N. Oncogenic human T-cell lymphotropic virus type 1 tax suppression of primary innate immune signaling pathways. J. Virol. 2015, 89, 4880-4893. [CrossRef] [PubMed]

84. Yuen, C.K.; Chan, C.P.; Fung, S.Y.; Wang, P.H.; Wong, W.M.; Tang, H.M.; Yuen, K.S.; Jin, D.Y.; Kok, K.H. Suppression of Type I Interferon Production by Human T-Cell Leukemia Virus Type 1 Oncoprotein Tax through Inhibition of IRF3 Phosphorylation. J. Virol. 2016, 90, 3902-3912. [CrossRef] [PubMed]

85. Wang, J.; Yang, S.; Liu, L.; Wang, H.; Yang, B. HTLV-1 Tax impairs K63-linked ubiquitination of STING to evade host innate immunity. Virus Res. 2017, 232, 13-21. [CrossRef]

86. Suzuki, S.; Zhou, Y.; Refaat, A.; Takasaki, I.; Koizumi, K.; Yamaoka, S.; Tabuchi, Y.; Saiki, I.; Sakurai, H. Human $\mathrm{T}$ cell lymphotropic virus 1 manipulates interferon regulatory signals by controlling the TAK1-IRF3 and IRF4 pathways. J. Biol. Chem. 2010, 285, 4441-4446. [CrossRef]

87. Diani, E.; Avesani, F.; Bergamo, E.; Cremonese, G.; Bertazzoni, U.; Romanelli, M.G. HTLV-1 Tax protein recruitment into IKK $\varepsilon$ and TBK1 kinase complexes enhances IFN-I expression. Virology 2015, 476, 92-99. [CrossRef]

88. Sze, A.; Belgnaoui, S.M.; Olagnier, D.; Lin, R.; Hiscott, J.; van Grevenynghe, J. Host restriction factor SAMHD1 limits human $\mathrm{T}$ cell leukemia virus type 1 infection of monocytes via STING-mediated apoptosis. Cell Host Microbe 2013, 14, 422-434. [CrossRef]

89. Wang, J.; Kang, L.; Song, D.; Liu, L.; Yang, S.; Ma, L.; Guo, Z.; Ding, H.; Wang, H.; Yang, B. Ku70 Senses HTLV-1 DNA and Modulates HTLV-1 Replication. J. Immunol. 2017, 199, 2475-2482. [CrossRef]

90. Yang, B.; Song, D.; Liu, Y.; Cui, Y.; Lu, G.; Di, W.; Xing, H.; Ma, L.; Guo, Z.; Guan, Y.; et al. IFI16 regulates HTLV-1 replication through promoting HTLV-1 RTI-induced innate immune responses. FEBS Lett. 2018, 592, 1693-1704. [CrossRef]

91. Colisson, R.; Barblu, L.; Gras, C.; Raynaud, F.; Hadj-Slimane, R.; Pique, C.; Hermine, O.; Lepelletier, Y.; Herbeuval, J.P. Free HTLV-1 induces TLR7-dependent innate immune response and TRAIL relocalization in killer plasmacytoid dendritic cells. Blood 2010, 115, 2177-2185. [CrossRef] [PubMed] 
92. Hishizawa, M.; Imada, K.; Kitawaki, T.; Ueda, M.; Kadowaki, N.; Uchiyama, T. Depletion and impaired interferon- $\alpha$-producing capacity of blood plasmacytoid dendritic cells in human T-cell leukaemia virus type I-infected individuals. Br. J. Haematol. 2004, 125, 568-575. [CrossRef] [PubMed]

93. Azakami, K.; Sato, T.; Araya, N.; Utsunomiya, A.; Kubota, R.; Suzuki, K.; Hasegawa, D.; Izumi, T.; Fujita, H.; Aratani, S.; et al. Severe loss of invariant NKT cells exhibiting anti-HTLV-1 activity in patients with HTLV-1-associated disorders. Blood 2009, 114, 3208-3215. [CrossRef] [PubMed]

94. Manuel, S.L.; Sehgal, M.; Khan, Z.K.; Goedert, J.J.; Betts, M.R.; Jain, P. An Altered Maturation and Adhesion Phenotype of Dendritic Cells in Diseased Individuals Compared to Asymptomatic Carriers of Human T Cell Leukemia Virus Type 1. AIDS Res. Hum. Retroviruses 2013, 29, 1273-1285. [CrossRef] [PubMed]

95. Neco, H.V.P.D.C.; Teixeira, V.G.D.S.; da Trindade, A.C.L.; Magalhães, P.M.R.; de Lorena, V.M.B.; Castellano, L.R.C.; de Souza, J.R.; Vasconcelos, L.R.; de Moura, P.M.M.F.; de Morais, C.N.L. Mediators Go Together: High Production of CXCL9, CXCL10, IFN- $\gamma$, and TNF- $\alpha$ in HTLV-1-Associated Myelopathy/Tropical Spastic Paraparesis. AIDS Res. Hum. Retroviruses 2017, 33, 1134-1139. [CrossRef]

96. Starling, A.L.B.; Martins-Filho, O.A.; Lambertucci, J.R.; Labanca, L.; de Souza Pereira, S.R.; Teixeira-Carvalho, A.; Martins, M.L.; Ribas, J.G.; Carneiro-Proietti, A.B.F.; Gonçalves, D.U. Proviral load and the balance of serum cytocines in HTLV-1-asymptomatic infection and in HTLV-1-associated myelopathy/tropical spastic paraparesis (HAM/TSP). Acta Trop. 2013, 125, 75-81. [CrossRef] [PubMed]

97. Tendler, C.L.; Greenberg, S.J.; Burton, J.D.; Danielpour, D.; Kim, S.-J.; Blattner, W.A.; Manns, A.; Waldmann, T.A. Cytokine induction in HTLV-I associated myelopathy and adult T-cell leukemia: Alternate molecular mechanisms underlying retroviral pathogenesis. J. Cell. Biochem. 1991, 46, 302-311. [CrossRef]

98. Goncalves, D.U.; Proietti, F.A.; Barbosa-Stancioli, E.F.; Martins, M.L.; Ribas, J.G.; Martins-Filho, O.A.; Teixeira-Carvalho, A.; Peruhype-Magalhães, V.; Carneiro-Proietti, A.B. HTLV-1-associated myelopathy/tropical spastic paraparesis (HAM/TSP) inflammatory network. Inflamm. Allergy Drug Targets 2008, 7, 98-107. [CrossRef]

99. Uchiyama, T. Human T Cell Leukemia Virus Type I (htlv-I) and Human Diseases. Annu. Rev. Immunol. 1997, 15, 15-37. [CrossRef]

100. Sonar, S.A.; Shaikh, S.; Joshi, N.; Atre, A.N.; Lal, G. IFN- $\gamma$ promotes transendothelial migration of CD4+ T cells across the blood-brain barrier. Immunol. Cell Biol. 2017, 95, 843-853. [CrossRef]

101. Yamano, Y.; Coler-Reilly, A. HTLV-1 induces a Th1-like state in CD4+CCR4+ T cells that produces an inflammatory positive feedback loop via astrocytes in HAM/TSP. J. Neuroimmunol. 2017, 304, 51-55. [CrossRef] [PubMed]

102. Afonso, P.V.; Ozden, S.; Prevost, M.-C.; Schmitt, C.; Seilhean, D.; Weksler, B.; Couraud, P.-O.; Gessain, A.; Romero, I.A.; Ceccaldi, P.-E. Human Blood-Brain Barrier Disruption by Retroviral-Infected Lymphocytes: Role of Myosin Light Chain Kinase in Endothelial Tight-Junction Disorganization. J. Immunol. 2007, 179, 2576-2583. [CrossRef]

103. Afonso, P.V.; Ozden, S.; Cumont, M.-C.; Seilhean, D.; Cartier, L.; Rezaie, P.; Mason, S.; Lambert, S.; Huerre, M.; Gessain, A.; et al. Alteration of blood-brain barrier integrity by retroviral infection. PLoS Pathog. 2008, 4, e1000205. [CrossRef] [PubMed]

104. Montanheiro, P.; Vergara, M.P.P.; Smid, J.; da Silva Duarte, A.J.; de Oliveira, A.C.P.; Casseb, J. High production of RANTES and MIP-1 $\alpha$ in the tropical spastic paraparesis/HTLV-1-associated myelopathy (TSP/HAM). J. Neuroimmunol. 2007, 188, 138-142. [CrossRef]

105. Brito-Melo, G.E.A.; Peruhype-Magalhães, V.; Teixeira-Carvalho, A.; Barbosa-Stancioli, E.F.; Carneiro-Proietti, A.B.F.; Catalan-Soares, B.; Ribas, J.G.; Martins-Filho, O.A. IL-10 produced by $\mathrm{CD} 4+$ and CD8+ $\mathrm{T}$ cells emerge as a putative immunoregulatory mechanism to counterbalance the monocyte-derived TNF- $\alpha$ and guarantee asymptomatic clinical status during chronic HTLV-I infection. Clin. Exp. Immunol. 2007, 147, 35-44. [CrossRef]

106. Fujimoto, T.; Nakamura, T.; Furuya, T.; Nakane, S.; Shirabe, S.; Kambara, C.; Hamasaki, S.; Yoshimura, T.; Eguchi, K. Relationship between the clinical efficacy of pentoxifylline treatment and elevation of serum $\mathrm{T}$ helper type 2 cytokine levels in patients with human T-lymphotropic virus type I-associated myelopathy. Intern. Med. 1999, 38, 717-721. [CrossRef]

107. Ali, A.; Rudge, P.; Dalgleish, A.G. Neopterin concentrations in serum and cerebrospinal fluid in HTLV-I infected individuals. J. Neurol. 1992, 239, 270-272. 
108. Tarokhian, H.; Taghadosi, M.; Rafatpanah, H.; Rajaei, T.; Azarpazhooh, M.R.; Valizadeh, N.; Rezaee, S.A.R. The effect of HTLV-1 virulence factors (HBZ, Tax, proviral load), HLA class I and plasma neopterin on manifestation of HTLV-1 associated myelopathy tropical spastic paraparesis. Virus Res. 2017, 228, 1-6. [CrossRef]

109. Sato, T.; Coler-Reilly, A.; Utsunomiya, A.; Araya, N.; Yagishita, N.; Ando, H.; Yamauchi, J.; Inoue, E.; Ueno, T.; Hasegawa, Y.; et al. CSF CXCL10, CXCL9, and neopterin as candidate prognostic biomarkers for HTLV-1-associated myelopathy/tropical spastic paraparesis. PLoS Negl. Trop. Dis. 2013, 7, e2479. [CrossRef]

110. Ando, H.; Sato, T.; Tomaru, U.; Yoshida, M.; Utsunomiya, A.; Yamauchi, J.; Araya, N.; Yagishita, N.; Coler-Reilly, A.; Shimizu, Y.; et al. Positive feedback loop via astrocytes causes chronic inflammation in virus-associated myelopathy. Brain 2013, 136, 2876-2887. [CrossRef]

111. Chaves, D.G.; Sales, C.C.; de Cássia Gonçalves, P.; da Silva-Malta, M.C.F.; Romanelli, L.C.; Ribas, J.G.; de Freitas Carneiro-Proietti, A.B.; Martins, M.L. Plasmatic proinflammatory chemokines levels are tricky markers to monitoring HTLV-1 carriers. J. Med. Virol. 2016, 88, 1438-1447. [CrossRef] [PubMed]

112. Araya, N.; Sato, T.; Ando, H.; Tomaru, U.; Yoshida, M.; Coler-Reilly, A.; Yagishita, N.; Yamauchi, J.; Hasegawa, A.; Kannagi, M.; et al. HTLV-1 induces a Th1-like state in CD4+CCR4+ T cells. J. Clin. Investig. 2014, 124, 3431-3442. [CrossRef] [PubMed]

113. Lehky, T.J.; Fox, C.H.; Koenig, S.; Levin, M.C.; Flerlage, N.; Izumo, S.; Sato, E.; Raine, C.S.; Osame, M.; Jacobson, S. Detection of human T-lymphotropic virus type I (HTLV-I) tax RNA in the central nervous system of HTLV-I-associated myelopathy/tropical spastic paraparesis patients by in situ hybridization. Ann. Neurol. 1995, 37, 167-175. [CrossRef] [PubMed]

114. Levin, M.C.; Rosenblum, M.K.; Fox, C.H.; Jacobson, S. Localization of retrovirus in the central nervous system of a patient co-infected with HTLV-1 and HIV with HAM/TSP and HIV-associated dementia. J. Neurovirol. 2001, 7, 61-65. [CrossRef] [PubMed]

115. Méndez, E.; Kawanishi, T.; Clemens, K.; Siomi, H.; Soldan, S.S.; Calabresi, P.; Brady, J.; Jacobson, S. Astrocyte-specific expression of human T-cell lymphotropic virus type 1 (HTLV-1) Tax: Induction of tumor necrosis factor $\alpha$ and susceptibility to lysis by CD8+ HTLV-1-specific cytotoxic T cells. J. Virol. 1997, 71, 9143-9149. [PubMed]

116. Szymocha, R.; Brisson, C.; Bernard, A.; Akaoka, H.; Belin, M.F.; Giraudon, P. Long-term effects of HTLV-1 on brain astrocytes: Sustained expression of Tax-1 associated with synthesis of inflammatory mediators. J. Neurovirol. 2000, 6, 350-357. [CrossRef] [PubMed]

117. Banerjee, P.; Rochford, R.; Antel, J.; Canute, G.; Wrzesinski, S.; Sieburg, M.; Feuer, G. Proinflammatory cytokine gene induction by human T-cell leukemia virus type 1 (HTLV-1) and HTLV-2 Tax in primary human glial cells. J. Virol. 2007, 81, 1690-1700. [CrossRef]

118. Iwatsuki, K.; Harada, H.; Motoki, Y.; Kaneko, F.; Jin, F.; Takigawa, M. Diversity of immunobiological functions of T-cell lines established from patients with adult T-cell leukaemia. Br. J. Dermatol. 1995, 133, 861-867. [CrossRef]

119. Micallef, M.; Ariyasu, T.; Dao, T.; Matsuo, Y.; Minowada, J. Constitutive expression of immunosuppressionassociated cytokine genes in a panel of human T-leukemia-cell lines-High-incidence of transforming growth-factor-Beta gene-expression. Int. J. Oncol. 1994, 4, 633-638. [CrossRef]

120. Mitre, E.; Thompson, R.W.; Carvalho, E.M.; Nutman, T.B.; Neva, F.A. Majority of interferongamma-producing CD4+ cells in patients infected with human T cell lymphotrophic virus do not express tax protein. J. Infect. Dis. 2003, 188, 428-432. [CrossRef]

121. Brown, D.A.; Nelson, F.B.; Reinherz, E.L.; Diamond, D.J. The human interferon-gamma gene contains an inducible promoter that can be transactivated by tax I and II. Eur. J. Immunol. 1991, 21, 1879-1885. [CrossRef] [PubMed]

122. Kannagi, M.; Harashima, N.; Kurihara, K.; Ohashi, T.; Utsunomiya, A.; Tanosaki, R.; Masuda, M.; Tomonaga, M.; Okamura, J. Tumor immunity against adult T-cell leukemia. Cancer Sci. 2005, 96, 249-255. [CrossRef] [PubMed]

123. Mitra-Kaushik, S.; Harding, J.; Hess, J.; Schreiber, R.; Ratner, L. Enhanced tumorigenesis in HTLV-1 tax-transgenic mice deficient in interferon-gamma. Blood 2004, 104, 3305-3311. [CrossRef] [PubMed] 
124. Kim, S.J.; Kehrl, J.H.; Burton, J.; Tendler, C.L.; Jeang, K.T.; Danielpour, D.; Thevenin, C.; Kim, K.Y.; Sporn, M.B.; Roberts, A.B. Transactivation of the transforming growth factor $\beta 1$ (TGF- $\beta$ 1) gene by human T lymphotropic virus type 1 tax: A potential mechanism for the increased production of TGF- $\beta 1$ in adult T cell leukemia. J. Exp. Med. 1990, 172, 121-129. [CrossRef]

125. Niitsu, Y.; Urushizaki, Y.; Koshida, Y.; Terui, K.; Mahara, K.; Kohgo, Y.; Urushizaki, I. Expression of TGF- $\beta$ gene in adult $\mathrm{T}$ cell leukemia. Blood 1988, 71, 263-266.

126. Huang, S.S.; Huang, J.S. TGF- $\beta$ control of cell proliferation. J. Cell. Biochem. 2005, 96, 447-462. [CrossRef]

127. Höllsberg, P.; Ausubel, L.J.; Hafler, D.A. Human T cell lymphotropic virus type I-induced T cell activation. Resistance to TGF- $\beta$ 1-induced suppression. J. Immunol. 1994, 153, 566-573.

128. Grant, C.; Oh, U.; Yao, K.; Yamano, Y.; Jacobson, S. Dysregulation of TGF- $\beta$ signaling and regulatory and effector T-cell function in virus-induced neuroinflammatory disease. Blood 2008, 111, 5601-5609. [CrossRef]

129. Mori, N.; Morishita, M.; Tsukazaki, T.; Giam, C.Z.; Kumatori, A.; Tanaka, Y.; Yamamoto, N. Human T-cell leukemia virus type I oncoprotein Tax represses Smad-dependent transforming growth factor $\beta$ signaling through interaction with CREB-binding protein/p300. Blood 2001, 97, 2137-2144. [CrossRef]

130. Lee, D.K.; Kim, B.-C.; Brady, J.N.; Jeang, K.-T.; Kim, S.-J. Human T-cell lymphotropic virus type 1 tax inhibits transforming growth factor- $\beta$ signaling by blocking the association of Smad proteins with Smad-binding element. J. Biol. Chem. 2002, 277, 33766-33775. [CrossRef]

131. Arnulf, B.; Villemain, A.; Nicot, C.; Mordelet, E.; Charneau, P.; Kersual, J.; Zermati, Y.; Mauviel, A.; Bazarbachi, A.; Hermine, O. Human T-cell lymphotropic virus oncoprotein Tax represses TGF- $\beta 1$ signaling in human T cells via c-Jun activation: A potential mechanism of HTLV-I leukemogenesis. Blood 2002, 100, 4129-4138. [CrossRef]

132. Zhao, T.; Satou, Y.; Sugata, K.; Miyazato, P.; Green, P.L.; Imamura, T.; Matsuoka, M. HTLV-1 bZIP factor enhances TGF- $\beta$ signaling through p300 coactivator. Blood 2011, 118, 1865-1876. [CrossRef] [PubMed]

133. Kulkarni, A.; Taylor, G.P.; Klose, R.J.; Schofield, C.J.; Bangham, C.R. Histone H2A monoubiquitylation and p38-MAPKs regulate immediate-early gene-like reactivation of latent retrovirus HTLV-1. JCI Insight 2018, 3, e123196. [CrossRef] [PubMed]

134. Chen, W.; Jin, W.; Hardegen, N.; Lei, K.-J.; Li, L.; Marinos, N.; McGrady, G.; Wahl, S.M. Conversion of peripheral CD4+CD25- naive T cells to CD4+CD25+ regulatory T cells by TGF- $\beta$ induction of transcription factor Foxp3. J. Exp. Med. 2003, 198, 1875-1886. [CrossRef] [PubMed]

135. Satou, Y.; Utsunomiya, A.; Tanabe, J.; Nakagawa, M.; Nosaka, K.; Matsuoka, M. HTLV-1 modulates the frequency and phenotype of FoxP3+CD4+ T cells in virus-infected individuals. Retrovirology 2012, 9, 46. [CrossRef] [PubMed]

136. Toulza, F.; Nosaka, K.; Tanaka, Y.; Schioppa, T.; Balkwill, F.; Taylor, G.P.; Bangham, C.R.M. Human Tlymphotropic virus type 1-induced CC chemokine ligand 22 maintains a high frequency of functional FoxP3+ regulatory T cells. J. Immunol. 2010, 185, 183-189. [CrossRef]

137. Toulza, F.; Nosaka, K.; Takiguchi, M.; Pagliuca, T.; Mitsuya, H.; Tanaka, Y.; Taylor, G.P.; Bangham, C.R.M. FoxP3+ regulatory $\mathrm{T}$ cells are distinct from leukemia cells in HTLV-1-associated adult T-cell leukemia. Int. J. Cancer 2009, 125, 2375-2382. [CrossRef]

138. Mori, N.; Gill, P.S.; Mougdil, T.; Murakami, S.; Eto, S.; Prager, D. Interleukin-10 gene expression in adult T-cell leukemia. Blood 1996, 88, 1035-1045. [CrossRef]

139. Kchour, G.; Rezaee, R.; Farid, R.; Ghantous, A.; Rafatpanah, H.; Tarhini, M.; Kooshyar, M.M.; El Hajj, H.; Berry, F.; Mortada, M.; et al. The combination of arsenic, interferon- $\alpha$, and zidovudine restores an "immunocompetent-like" cytokine expression profile in patients with adult T-cell leukemia lymphoma. Retrovirology 2013, 10, 91. [CrossRef]

140. Yasuma, K.; Yasunaga, J.; Takemoto, K.; Sugata, K.; Mitobe, Y.; Takenouchi, N.; Nakagawa, M.; Suzuki, Y.; Matsuoka, M. HTLV-1 bZIP Factor Impairs Anti-viral Immunity by Inducing Co-inhibitory Molecule, T Cell Immunoglobulin and ITIM Domain (TIGIT). PLoS Pathog. 2016, 12, e1005372. [CrossRef]

141. Datta, A.; Sinha-Datta, U.; Dhillon, N.K.; Buch, S.; Nicot, C. The HTLV-I p30 interferes with TLR4 signaling and modulates the release of pro- and anti-inflammatory cytokines from human macrophages. J. Biol. Chem. 2006, 281, 23414-23424. [CrossRef] [PubMed]

142. Sabat, R.; Grütz, G.; Warszawska, K.; Kirsch, S.; Witte, E.; Wolk, K.; Geginat, J. Biology of interleukin-10. Cytokine Growth Fact. Rev. 2010, 21, 331-344. [CrossRef] [PubMed] 
143. Blackburn, S.D.; Wherry, E.J. IL-10, T cell exhaustion and viral persistence. Trends Microbiol. 2007, 15, $143-146$. [CrossRef] [PubMed]

144. Lamichhane, P.; Karyampudi, L.; Shreeder, B.; Krempski, J.; Bahr, D.; Daum, J.; Kalli, K.R.; Goode, E.L.; Block, M.S.; Cannon, M.J.; et al. IL10 Release upon PD-1 Blockade Sustains Immunosuppression in Ovarian Cancer. Cancer Res. 2017, 77, 6667-6678. [CrossRef] [PubMed]

145. Kozako, T.; Yoshimitsu, M.; Fujiwara, H.; Masamoto, I.; Horai, S.; White, Y.; Akimoto, M.; Suzuki, S.; Matsushita, K.; Uozumi, K.; et al. PD-1/PD-L1 expression in human T-cell leukemia virus type 1 carriers and adult T-cell leukemia/lymphoma patients. Leukemia 2009, 23, 375-382. [CrossRef]

146. Shimauchi, T.; Kabashima, K.; Nakashima, D.; Sugita, K.; Yamada, Y.; Hino, R.; Tokura, Y. Augmented expression of programmed death-1 in both neoplastic and non-neoplastic CD4+ T-cells in adult T-cell leukemia/lymphoma. Int. J. Cancer 2007, 121, 2585-2590. [CrossRef]

147. Masaki, A.; Ishida, T.; Suzuki, S.; Ito, A.; Narita, T.; Kinoshita, S.; Ri, M.; Kusumoto, S.; Komatsu, H.; Inagaki, H.; et al. Human T-cell lymphotropic/leukemia virus type 1 (HTLV-1) Tax-specific T-cell exhaustion in HTLV-1-infected individuals. Cancer Sci. 2018, 109, 2383-2390. [CrossRef]

148. Kozako, T.; Arima, N.; Toji, S.; Masamoto, I.; Akimoto, M.; Hamada, H.; Che, X.-F.; Fujiwara, H.; Matsushita, K.; Tokunaga, M.; et al. Reduced frequency, diversity, and function of human T cell leukemia virus type 1-specific CD8+ T cell in adult T cell leukemia patients. J. Immunol. 2006, 177, 5718-5726. [CrossRef]

149. Espíndola, O.M.; Oliveira, L.C.; Ferreira, P.M.S.; Leite, A.C.C.B.; Lima, M.A.S.D.; Andrada-Serpa, M.J. High IFN- $\gamma /$ IL-10 expression ratio and increased frequency of persistent human T-cell lymphotropic virus type 1-infected clones are associated with human T-cell lymphotropic virus type 1-associated myelopathy/tropical spastic paraparesis development. Intervirology 2015, 58, 106-114. [CrossRef]

(C) 2018 by the authors. Licensee MDPI, Basel, Switzerland. This article is an open access article distributed under the terms and conditions of the Creative Commons Attribution (CC BY) license (http:/ / creativecommons.org/licenses/by/4.0/). 